\title{
Sustainable Development - Balance of Economic Growth and Ecosystem Health
}

\author{
Zoran Bajić ${ }^{1}$ \\ ${ }^{1}$ SaTCIP d.o.o, Tržni centar Pijaca 106, Vrnjačka Banja
}

\begin{abstract}
In the new epoch (end of 20th and beginning of the 21th century), due to the strong development of the productive forces and the uncontrolled exploitation of natural resources, there has been a disruption of ecological balance. We are facing an ever faster disappearance of balance between natural systems to sustain life and progressive economic and scientific and technological needs of humanity.

Preservation of the living environment, and within that, specifically, sustainable development, is one of the most important problems facing the world of our day. It is necessary rethinking of social development - sustainable development, ie. Seeking a balance between economic growth and the health of ecosystems.

Hand in hand with the idea and concept of sustainable development is going protection of biodiversity - the protection of life (biodiversity). Inexorable law of the biosphere is that the non-functioning of mutual processes of spontaneous circulation of energy, life stops.

The problem of sustainable development engages the attention of science in general, and especially of modern ecological economics aimed at restricting economic growth when it reaches the stage where there is a "depletion" of man's environment, ie. endangering natural resources - due consideration to the fact that economic and environmental system are two parts of a whole.

Demographic explosion, also one of the acute problems of the contemporary world, raises serious questions about sustainable development. On the planet there is no more free places for such an increase in population, and it is increasingly difficult to feed. In addition, population explosion, increase atmospheric pollution and contributes to approaching threats of the "thermal limits".
\end{abstract}

Keywords: Sustainable development, ecosphere-ecosystem, biosphere-biodiversity, ecological economics, demographic explosion.

\section{INTRODUCTION}

In the third epoch (IT) and the upcoming fourth (knowledge society) scientific and technological revolution, due to the rapid and strong development of the productive forces and the ruthless and uncontrolled "depletion" of the natural environment, there was a disruption of ecological balance - endangering the survival of all life on planet of the Earth.

Humanity has until recently lived in the belief that thanks to computers and technology can "produce nature" and that it can "produce and what nature has not been able, for example, new means of communication, detergents, pesticides, psycho drugs and others." [8]. There was no conscious that it is, precisely, "with such activities of a man has been disrupted the basic ecological principle, according to which everything that man produces and it does not exist in nature must be harmful to other living beings, as in nature, there are environmental influence and connection" [8].

Today, humanity may face an ever faster disappearance of balance between natural systems to sustain life and the need for progressive scientifictechnological and economic development. These two (seemingly incongruous) problems should be solved simultaneously and structurally, said in a word, ecology and economy must be two sides of the same process. It's required is a new and profound rationality in the appropriation of nature - it is necessary to harmonize environmental and economic needs. One of the most important tasks of science consists in the elaboration of such economic system, which will provide a high pace of economic growth and provided that as small as possible damage to the natural environment (underlined Z. B.) "[12]. It can be solved only by modern ecological economics, based on a broader, more comprehensive (not a classic, which takes into account only the market demands), the economic approach. It's concerned to the modern ecological - economic approach which must be based on the fact that "the degradation of the environment is not the product of temporary and random disorder nor a product of technological development. On the contrary, it is a system of the deepest structures of a form of industrial civilization, one mode of production "[21]. The degradation of the natural environment from day to day gets more dramatic proportions. "The number of unforeseen events from day to day increases and therefore are more difficult to predict ... Prediction means the ability to avoid anything" [11].

It is an encouraging fact that, in the last twenty years awareness and knowledge increasingly penetrate that the preservation of the living environment, and within that, specifically, sustainable development, is one of the most if not the most important problem facing the world of our day. Penetrates awareness and knowledge that is necessary rethinking of social development - sustainable development.

Specifically, the subject of this paper is Sustainable Development - a balance between economic growth and 
ecosystem health. For the purpose of precise and objective consideration of the essence and actuality of sustainable development, mainly, we will focus on the emergence and importance of the idea and the concept of sustainable development, as well as protection of biological diversity, the diversity of life on earth - biodiversity. Here we see two sub-groups: the concept of sustainable development and biodiversity. Since there is no sustainable development without adopting sustainable habits, we will try with the first subgroup - sustainable development, at least a little to strengthen it in a way that we will point out some experimental and project attempts in humans to encourage sustainable habits.

Then, we will, and this is the next part of this work, consider the efforts of modern ecological economics to find a balance between economy and ecology - between economic growth and ecosystem health.

Today, we are also witnesses of the fact that the dramatic demographic explosion directly challenges sustainable development. Prior to the conclusion we will point out the seriousness of the acute problem of modern mankind.

\section{EMERGENCE AND IMPORTANCE OF IDEAS AND CONCEPTS OF SUSTAINABLE DEVELOPMENT AND BIODIVERSITY PROTECTION}

Social, and above all economic, development of the last hundred years both is marked and followed by disastrous overutilization of all resources available to the planet of the Earth. The man is related to nature as to something foreign - something beyond what he is. We are witnesses to the fact that in modern society there was uncontrolled development of the productive forces and at the same time to the ruthless and irrational use of natural resources.

Only in the last twenty years is beginning to penetrate the consciousness and awareness that "people are not unlimited masters of nature and to disruption of the ecological balance in nature, which was created by man's activities aimed at the appropriation of nature can lead to compromising the conditions of human life on earth" [12].

Within that the central place occupies an idea and the concept of sustainable development, ie. Seeking for a balance between economic growth and ecosystem health.

Hand in hand with the idea and the concept of sustainable development goes and protection of biological diversity, the diversity of life on Earth - biodiversity. Thus, it is scientifically proven that human life on earth depends on the life of a thousand species of plants, animals and micro-organisms.

1.1. Emergence and importance of the idea and concept of sustainable development

The term sustainability comes from the Latin word Sustineo, sustento and means to resist, to last.

The idea of sustainable development, "although belongs to the younger notions and new concepts, resulting in few decades, today occupies a very important place" [18]. Although, we can see that this is concerned to the idea and the concept of only a few decades old, it is important to mention that the very concept of sustainable development for the first time was mentioned in 1713, and was related to the maintenance of the forests. "Even at that time it was concluded that there was the excessive cutting of forests for timbers and that it is not an inexhaustible resource. But then was realized that "only could be cut down as many trees as the new seedlings are planted." This ecological principle can be applied to a variety of natural resources and ecological systems "[7]. The idea of sustainable development is primarily related to rationality and uniformity of use of resources, in order to preserve for future generations the natural advantages and beauty. Or, more precisely, the optimal solution of ecological problems with unimpeded economic development and scientific - technological progress.

The emergence of the idea of sustainable development occurred when scientific researchers of social reality discovered two important conclusions: "(1) that there was a discrepancy between the basic spheres of the man's social life (politics, economy, culture, technology and ecology) and (2) that there is a significant imbalance between the developmental needs of man and society, on the one hand, and nature, on the other hand "[10]. This is a new thinking of development in the sense of leaving the quantitative approach, which is the special contribution made by the Declaration of the United Nations Conference of Human Environment approved in Stockholm in 1972. In the Declaration specifically emphasizes "the need to develop the ability to preserve our planet that produces the main natural resources, and to use non-renewable wealth in a way that will not be exhausted" [4].

The concept of sustainable development "was created as a response to major ecological debate that took place since 1968 and the emergence of the first report of the Club of Rome published in the book" The Limits of Growth (1972) (Meadows at.al .., 1974) [18]. Great incentive to the concept of sustainable development was given by the World Commission on Environment and Development, which in 1987 filed a report entitled "Our Common Future". There has been pointed out the consequences on the environment that can have uncontrolled population and economic growth. The Second United Nations Conference on the Human Environment held in 1992 in Rio de Janeiro, "proclaimed the concept of sustainable development as a method of solving of environmental problems on a global and local level" [24]. The essence of the concept of sustainable development is the effort to find the optimal solutions for solving environmental problems, provided that solutions do not impede economic development and scientific technological progress. "In the context of this new approach related to the definition of development, there has been pointed out the need to take in designing of economically and ecologically rational development strategy to recognizes the need to protect renewable natural resources and in this sense the formation of prices of natural resources required to maintain the cost of their replacement" [12].

The concept of sustainable development is much more complicated, more complex and broader concept of development than the classical concept of socio economic development. One would say that it is a multidisciplinary concept, because sustainable development has four components: economical technological, social, cultural and environmental. 
Francesco di Kaspar says that "sustainable development can only work when the four pillars of development economic, social, cultural and environment - are of equal importance and strength, with strong interconnectedness and conditionality. If a leg of the chair is shorter or longer than the other, there is no comfortable seating, no sustainability "[24]. Just starting from the complexity of the concept of sustainable development, it is certain that it must be approached multidisciplinary, ie. that the solution of this problem must include not only experts in the field of human ecology, ecological economics and technology, but also culturologists, sociologists and demographers. Of course, it is the expectation that the top of the political elite support this, not so simple project. As a "man's relation to nature is mediated by the political system, so the ecological policies are determined by government policy which is realized, as a social and political dimension substantially determine attitude and behavior of social communities towards the existing natural resources" [20]. In addition, of course, "the democratic character of the political system is more conducive to the establishment of environmentally desirable and healthy relationship of man and society to nature than non-democratic organization of the state and political institutions" [21].

1.1.1. Renewable and non-renewable natural resources and the limits of sustainability

Natural resources are divided into two groups: renewable and non-renewable.

First, when it comes to renewable resources, first we can talk about natural (environmental) sustainability the ability of regeneration and the life of the ecosystem (for example, large forest systems). Then we can talk about the sustainability of renewable resources in terms of their balanced use, as well as rational availability of renewable resources.

Second, non-renewable natural resources are those quantities of which are limited (for example, oil reserves, mineral resources, etc.). It is the problem of uncontrolled exploitation, the nowadays problem. "Modern industrial societies have based their expansive development in the last few centuries, primarily, on the use of these kinds of resources" [18].

We do not know exactly where are the limits of sustainability, but it is certain that we are very close to them. In some cases and in some areas, these borders are even breached. "The pressure of humanity on the ecosystem and the climate is unsustainable because it causes dangerous climate problems, the mass extinction of species and the destruction of the key factors that support life on earth" [26].

Today, global warming and climate changes are one of the most dramatic problems of our era. "There are credible assurances that it might soon due to climate change and its conditioned reactions to deepen conflicts or wars may break out, when for a few decades will be flooded many parts and the mainland of the poor state of India, Bangladesh, Southern Italy ... Policy of climate changes, today, are one of the greatest experiences for the future of the world and peace in it"[6].

How to behave, how, generally speaking, solve the problem of sustainable development? Solving the problem is, above all, in the "encounter of ethics and economics" [2] - in reconciling of ecology and economics. The solution lies in the rational, ie. controlled use of natural resources, because only it can ensure a sustainable future. The concept of sustainable development is based on a new theory of growth rather than the exploitation of natural resources, as a key determinant of economic growth and development takes the ability to exercise and application of new knowledge, especially knowledge of modern ecological economics.

It should be emphasized that the sustainable development of the Lisbon Treaty on the establishment of the European Union is highlighted as the ultimate longterm goal of this community. To achieve a sustainable future, the European Union adopted the Europe strategy 2020 , which is focused on a sustainable future.

The most acceptable designation of the essence of sustainable development is given in the book, "Our Common Future", built on the basis of the report of the European Commission on Environment and Development in 1987, which is commonly accepted as the official definition of sustainable development. In a word, it is concluded that sustainable development is the development that meets the needs of the present without jeopardizing the ability of future generations.

Also, it's worth to say that there is no universal models of sustainable development. A specific approach is necessary to individual segments and certain regions. However, in general, it is required a new general ecological culture - a universal culture that are based on the construction of a new (active and humane attitude towards nature). The slogan of the new general ecological culture is: "To give more than take"!

1.1.2. Some experimental and project attemts to encourage sustainable habits in humans

The concept of sustainable development is one of the key issues of contemporary society. It is, however, a topic that is still largely discussed only in the scientific and academic - circles. It is essential that the issue of sustainable development take an interest of wide layers of population. It is necessary to encourage them to sustainable behavior, because without sustainable behavior there is no sustainable development. It is particularly an encouraging experience of Colin Bevan from New York known as the "No Impact Man" who, together with his family started to experiment for a year trying to leave no footprint on the planet. "They started with small steps: they stopped to use public transport, they moved on foot or by bicycle, carrying the linen bags for shopping and ate only locally produced seasonal food. Then they stopped producing waste by using only what they already had or have received from others. They threw away cosmetics from use, donated electronic devices to friends and at the end switched off the electricity in the apartment "[17].

This family during the year has noticed without what can and cannot live and on the way encouraged thousands of others on the activity of this type.

Inspired by the new experience of Colin Belvana, Ana Pantelic in our conditions has implemented the project "Sustainable habits for sustainable development". With the aim to determine "to what extent it is possible to 
change some aspects of behavior, was launched an activity under the slogan "Withstand and sustain!", which required from the participants to reduce their ecological footprint during one session (from 18 to 24 April 2011) to attempt to implement some new forms of behavior, and to persevere in the long run through a selection of new sustainable habits to be followed in the future "(17). Action "Withstand and sustain!", for which is registered 107 participants from all over of Serbia took place exclusively over the internet. "Each evening, participants received an information - experimental mail with suggestions on sustainable practices that the next day may adopt ... The participants were given advices on how to reduce the amount of water they use during the day. The fifth day of action was dedicated to transportation and participants were suggested that they often go on foot or by public transport instead of using a car or a taxi. It is interesting that the participants of this action, on average, spent nearly an hour and 45 minutes on the move. It is noticed a dramatic decrease in "unsustainable habits" but after the first day of action, which is nicely reflected in a gradual reduction of the number of people who have left the water running while brushing their teeth, hair, or shaving, as well as buying water in plastic containers. Notable is the drastic decline in the number of people who have left the electrical appliances included until they were not used "[17].

\subsection{Protection of biodiversity}

Often when we talk about sustainable development, at the same time it is talking about the need to harmonize economic activity with biological and physiological organisms, biological diversity of life on earth - on Biodiversity.

The most widely accepted definition is according to which "Biodiversity (biological diversity) means the totality of genes, species, ecosystems and landscapes on earth - a synonym for life on Earth" [22].

In particular, "Conference on Sustainability and Development in Rio de Janeiro, the concept

of biodiversity receives central position not only in the immediate biological but also in a wider social, economic and political terms," [22]. In fact, "all that is alive, it's alive because so long as work is very complex system of mutually conditioned process which is inherent spontaneous circulation of energy. It is an inexorable law of the biosphere, for with the termination of energy circulation and the life stops "[5]. In a word, the man is due to means that met the immediate needs (today's consumer mentality) destroyed large plants that keep the soil, which quickly led to the infertility of the soil, which is inhabited, dried up the sources, thus removing animals that found their life there - he destroyed everything around himself, so now he is in danger of uprooting himself. Today, "unfortunately can be concluded that the impact of humans on the environment have never been so intense, comprehensive and far-reaching. The warning alarm is turned on that natural resources cannot any longer be exploited in an uncontrolled and excessive way without consequences on the overall humanity (emphasized Z. B.) "[22]. Such an uncontrolled human action on the environment, "the number of species that are unjustifiably lost amounts to an amazing 27 thousand species per year, or 74 species per day. With hundreds of organic species disappeared in the course of a day, the rate of extinction becomes 1,000 times higher than the estimated natural rate of extinction of evolution. With this, according to its scales, could be compared only disaster that occurred 65 million years ago, when from the face of the Earth dinosaurs disappeared "[23]. In the book of Jean-Francois Richard "High Noon" assumes that one in five mammals and one of the nine birds are under threat of extinction.

Of particular importance for biodiversity protection is a historic UN conference - the Summit of Earth: United Nations Conference on Environment and Development (UNCED) held in Rio de Janeiro from 03. to June 14, 1992. At that conference, among other things, was approved the Declaration on Biological Diversity (CBD). And, finally, it should be noted that the UN General Assembly at its 65th meeting held on 22 December 2010 adopted resolution $65 / 161$, by which the period from 2011 to 2020 was declared the UN Decade of Biodiversity.

\section{MODERN ECOLOGICAL ECONOMY AND SUSTAINABLE DEVELOPMENT}

In general, the starting point of modern ecological economics is that "human activity must be limited with the capability of the environment (underlined Z. B.)" [15]. It is a new perception of economic growth and social progress. Modern ecological economy is based on broader economic approach (unlike to classical economics that takes into account only the laws of the market), that is based on the analysis of the ways in which the scope of economic activity affects the system of living environment. It is an entirely new economic approach in which "the market is no longer an universal regulator, ie the rational exploitation of natural resources - minimizing losses to the environment arisen due to man's ruthless and uncontrolled exploitation" [12]. In particular is emphasized that, the non-renewable resources (which do not have their substitution) must be protected at the cost of stopping economic growth.

The central place in contemporary ecological economy, that we see, is based on the rational use of natural resources (in order to preserve the natural beauty for future generations) takes the concept of sustainable development, ie seeking a balance between economic growth and development of the ecosystem. As the world's environmental problems, mainly, arising due to exhausting natural resources, it is entirely reasonable and understandable as modern ecological economics focuses on restricting economic growth, when it reaches a level at which begins "depletion" of a man's environment, ie endangering natural resources. Of course, ahead of modern environmental economics there is a very difficult and rather complex task. We said that in the solution of this problem must be included not only experts in the field of ecology, environmental economics and technology, but also culturologists, sociologists and demographers, including the top political elite. Because, at all, it's not easy to build one such, contemporary ecological economic system that will allow a high degree of economic growth without allowing to cause damage to natural resources - to appreciate the fact that ecological and economic system are two parts of one whole. What is 
necessary is an activist approach towards further improvement of finding new correlations between two systems "[12]. Often the question is what economic development is desirable? The answer to this question should be: "Sustainable development - development that needs to integrate previous experience, current practices and future vision" [16].

Therefore, sustainable development refers to the preservation of the health of ecosystems along the smooth development of economy and society. Sustainability means "outlining a new vision not only of economics and technology, but also culture, politics, medicine, or a new vision of the entire lifestyle and economy ... That means maintaining the capacity of the Earth to ensure quality of life and not yet born everyone of its future inhabitant" [12] - the sustainability of the natural beauty of our generation. For, we are, "as a known idea says, stemmed from the culture of American Indians, Planet Earth inherited from our sons, grandchildren and the generations to come after them" [18].

\section{DEMOGRAPHIC EXPLOSION AND SUSTAINABLE DEVELOPMENT}

The twentieth and beginning of the 21 st century have brought unprecedented already worrying increase in population on the planet. This increase gets such proportions that with a lot of ground can be said that this is one of the most serious problems facing the modern world. How serious is this problem can be seen from the following data. The human species appeared, according to estimates of the majority of scholars who deal with this issue before about 600000 years ago. By the end of the 19th century the number of people has increased approximately to one billion. Today, on this planet lives of 6.5 billion people. So, for the past 100 years, the number of inhabitants living on the planet has increased five times more than the increase amounted to 600 000. previous years. Estimates for the years ahead indicate that this trend will not only continue but there will be a further acceleration. Thus, for example, well-known international Commission on Environment and Development, which brings together the best-known experts in this field of study, less than a decade ago came out with the estimate that by 2025 the population of the planet will increase to 8.5 billion. Some experts predict that over the next 30 years, the increase could be higher [1].

This problem gets dramatic proportions, primarily, because it is not equally present in all parts of the world. Here we are facing a phenomenon that at first glance seems almost an incredible paradox: the population is growing fastest in the poorest parts of the world, in countries where for decades, millions of people are literally dying of hunger. It is estimated that in the next thirty years underdeveloped countries participate with $95 \%$ of the total population of the planet.

The rapid and uncontrolled growth of world population represents, due to a number of reasons, a very serious problem with which the world faces today. The most important reason is that on this planet there is no more "free sites" for such an increase in population. If today, when we are about 6.5 billion on the planet do not have enough food and other important resources, including water, necessary for the provision of decent living conditions for the entire population, what will happen when the number of people in 2025 will amount to 85 billion, or more later. To tell the truth, there are also present some more optimist estimates. According to some calculations of the World Bank, global population of the country can be stabilized at between 10 and 11 billion people in the second half of the 21 st century. There are demographers who expect that the average family size will be declined in the future, that urbanization and other factors will cause the demographic transition, and there will not be a significant increase in population in the future. However, "even if these predictions are correct and since the population is increasing globally, increase continues more than dying, the effect is as if a giant supertanker at sea begins to slow down. While slowing still there is a long way to go before it stops. Before we reach the level that is called "global changes of fertility", for which UN experts believe that it can happen around 2045. year "[9].

Problem of number and density of the population on Earth, as well as the adaptation of the human to the conditions of high population density has an ecological and socio-economic dimension. "There are physical limits ie. indicators that masses of people can live on Earth. For, as we all know, human life means processing of power, which leads to the release of a portion of the heat due to life processes. Thus, must be achieved "heat borders" due to the assembling of people. Huge population growth would endanger this limit. Thus, the human mass of a trillion create heat, which corresponds to the melting point of iron "[27]. Some even suggest that "if we continue with these demographic growth, after 2600.year, all human beings would be touching each other if would be able to feed, then you will have to eat standing up" [25]. Of course, it is unlikely that such a large number of people would be able to provide food, since humanity today faces a serious problem of malnourished people. "Over 450 million are chronically hungry or poorly nourished, and yearly die of starvation around 20 million people. The doubling of the population on Earth at the end of the century, will presumably seek at least doubled production of food, energy, machinery, new jobs and doubled the production of oxygen, natural resources and drinking water "[12]. Thus, the demographic explosion is one of the most acute problems of the modern world. It seriously threatens sustainable development - is threatening to reach the limits of growth on Earth. Because, "the most reliable way to reach this upper limit of growth is exponentially increasing and the number of inhabitants and the polluting activities of every person" [13]. From these data it can be concluded that the demographic problem in the years to come get not only serious but also frightening proportions. It is difficult to stop the growth of the population in the least developed countries in the world where today a large number of people are dying of hunger and where every day is an increasing environmental pollution - which seriously threatens the limits of growth.

\section{CONCLUSION}

Not in the so ancient past, it was thought that natural sources are inexhaustible - that can be used indefinitely and exploited. Today we are faced with a situation that so far the world has not known. For the first 
time in its history, mankind faced the crisis that concerns literally everyone, affects everything - all living beings, all plant life and all nations large and small, developed or developing. We are facing an ever faster disappearance of balance between the natural life-support systems and industrial, technological and demographic problems of mankind.

Specifically, social, and above all, economic development over the past hundred years is marked and followed not only with terrible overutilization of resources available to this planet, but also with the horrific destruction of some of the basic assumptions of life and survival of the human race, as well as some other species. Until very recently, these problems and this price of economic development almost have not been taken into consideration. Today, it is increasingly present opinion that this delay is of such proportions that it raises the question of whether there is still chance to resolve these problems [1]. In a word, "humanity at the present stage of scientific and technological processes is found at the crossroads: how to build our relationship towards nature and what to do in order not to over-spend its resources, without exacerbating the environment and developing the productive forces to meet the material and cultural needs of the people? "[14].

Generally, more than a century we prompt the question of ecology. Disturbance of natural balance reaches a point where it is increasingly difficult to reestablish. In this sense, one of the major problems facing our world is sustainable development - establishment of balance between economic growth and ecosystem health, harmonization of economic and ecological needs of humanity. Because in modern society there was uncontrolled development of the productive forces and the ruthless and irrational use of natural resources. Especially the big problem is an uncontrolled exploitation of nonrenewable natural resources, for upon them the modern industrial societies based their expansive development in the last two centuries.

With sustainable development is closely linked the problem of biodiversity, the issue of protection and conservation of biodiversity on Earth. Often when we talk about unsustainable development, at the same time is talking about the need to harmonize economic activity with biological and physiological organisms - with life on Earth.

The problem of sustainable development now occupies the attention of science in general. The greatest attention is given to the contemporary ecological economics. It puts itself in the task of development of economic systems which will ensure a high pace of economic growth and apply as small as possible damage to the natural environment, that restricts the possibilities for economic growth when it reaches the level at which begins endangering natural resources. It is about a modern activist procedure which seeks to harmonize economic and ecological system and find new correlations between the two systems.

The demographic explosion, the dramatic increase in population in the least developed countries of the world where for decades, millions of people are dying of hunger, is an acute problem of the modern world which most seriously threatens sustainable development. Even with today's number of inhabitants of the Earth are seriously endangered the limits of growth - and the "thermal limit" is threatened, and enormously is increased pollution of the human environment. There is a danger that in the years to come these problems get even more drastic proportions.

The samples follow:

[1] Bajić, Z.: Promišljanje i preispitivanje nekih socioloških kategorija, Aranđelovac: Grafopak, 2014 - str. 165 - 168: ISBN 978 - 86 - $85165-14-6$.

[2] Bajić, Z.: Kultura mira u planetarnim razmerama, Aranđelovac, Grafopak, 2014 - str. 73 - 79: ISBN $978-86-85-85165-16-0$.

[3] Beovan, C. (2009), no Impact Man: The Adventures of save the planet and the Discoveries He Makes about Himselant our Why of life i the process, New York: farrar, status and giroux.

[4] Deklaracija Konferencije Ujedinjenih nacija o čovekovoj sredini, Stockholm, 1982, princip 5.

[5] Despotović, R.: Ekologija i okolina, „Revija rada“, Beograd, 231/1990, star. b.

[6] Gidens, A. (2010), Klimatske promene i politika, Beograd: CLIO.

[7] Jegdić, V. (2010), „Međusektorska partnerstva, uslov održivog razvoja i odgovor na izazove globalizacije“, u: Socijalna misao 2/2010, str. 157 - 173.

[8] Kanazir, D.: Ekološka kriza je proizašla iz narušavanja odnosa čoveka i prirode, „Čovek i sredina“, Beograd, 1/1975, str. 8.

[9] Kennedy, P. (1987), The rise and fall at the great powers, New York, str. 38.

[10] Magdelinić, Z. , Ka sociološkom razumevanju održivog razvoja, u: Sociološki pregled god XLIV (2010), broj 1, str. $309-324$.

[11] Major, F.: Sutra je uvek kasno, ,Jugoslovenska revija“, Beograd, 1991, str. 202.

[12] Marković Ž.D. - Ilić B.B. - Ristić L.Ž., Ekološka ekonomija, Beograd, Etno Stil, 2012, str. 28 - 289.

[13] Meadovs D.H. - Meadovs D.L. - Ronders J. Behrens W.W., III, Granice rasta, Stvarnost, Zagreb, 1987.

[14] Ministarstvo za zaštitu životne sredine Republike Srbije, „Ekonomija Ekologije, Ekologija ekonomije“ (UNESCO), Beograd, 2009.

[15] Muller H., Turizam i ekologija, prevod, Zagreb, 2009.str. 40.

[16] Our Common Future: The World commission on Enviromental and Developoment Oxford Universsity press, Oxford, New York, 1987.

[17] Pantelić, A.,: Održivim navikama do održivog razvoja, u: Univerzitet i održivi razvoj, Faklutet političkih nauka, Univerzitet u Beogradu, Centar za ekološku politiku i održivi razvoj, priredio Vukašin Pavlović, str. 207: ISBN $978-86-8431-50-3$.

[18] Pavlović, V.,: Održivi razvoj i univerzitetsko obrazovanje, u: Univerzitet u Beogradu, Fakultet političkih nauka, Centar za ekološku politiku i održivi razvoj, 
priredio Vukašin Pavlović, Beograd, 2011, str. 13 - 31 ISBN $978-86-8431-50-3$.

[19] Pavlović, V.,: Poredak i alternativa, Nikšić, „Univerzitetska riječ“, 1987, str. 168.

[20] Pavlović, V.,: Društveni i politički značaj ekologije, Zbornik radova samoupravno društvo i ekolo0gija, 1987, starna 17.

[21] Pečujlić, M.,: Svetska ekonomska kriza i naše društvo, Zbornik radova, „Čovek, društvo, životna sredina, Beograd, 1987, str. 22.

[22] Radović, I.,: Međunarodna dekada biodiverziteta UN (2011 - 2020), u: Univerzitet i održivi razvoj, Fakultet političkih nauka, Univerzitet u Beogradu, Centar za politiku i održivi razvoj, Priredio Vukašin Pavlović, Beograd, 2011, str. 31 - 63: ISBN 978-86-8431-50- 3.
[23] Radović, I. (2006), Rizici i posledice narušavanja biodiverziteta: jedan od glavnih problema današnjice, u: Z.Keković, Ž. Keštović (ur), Krizni menadzment I, Prevencija krize: Univerzitet u Beogradu, Fakultet bezbednosti, str. $177-206$.

[24] Radulović, J i dr: Koncept održivog razvoja, Savezno ministarstvo za razvoj, Beograd, 1997, strana 11 - 13.

[25] Rougemont, D.:Budućnost je naša stvar, Književne novine, Beograd, 1987.

[26] Sach, J. ( 2008 ), Commont Wealth Economics for a crow death planet New York: Penguin Grow up ( USA ) inc.

[27] Stupec, R.,:Ova jedina zemlja, SNL, Zagreb, 1978. 